\title{
Integration Scheme of Information Management in Gongchangling Mining Corporation
}

\author{
LI Keqing, Wang Yiqiao, Ping Shuo \\ Key Laboratory of the Ministry of Education of China for High-Efficient Mining and Safety of Metal Mines, University of \\ Science and Technology Beijing \\ Beijing 100083, China \\ e-mail: lkqing2003@163.com
}

\begin{abstract}
On the basis of introducing application situation of information management in Gongchangling Mining Corporation, the advantage and disadvantage of $B / S$ mode and $\mathrm{C} / \mathrm{S}$ mode were analyzed. Respective characteristic of major developing technologies, such as JSP, ASP and PHP, had been compared. The feasibility of building office automation system based on B/S mode was discussed. The solving scheme of office automation system based $\mathbf{B} / \mathbf{S}$ mode in Gongchangling Mining Corporation is put forward while retaining the original $\mathrm{C} / \mathrm{S}$ system.
\end{abstract}

Keywords-Browse/Server; Client/Server; JSP; office automation

\section{INTRODUCTION}

With the development of information technology, the computer application level in China's mining enterprises is continuously improving. Many mines have leaped over the stage using computer to process single data, and begin to set up computer network system and gradually form their own management information system and even office automation system. Through applying of the system, these mines have achieved good economic benefit and social benefit. However, due to insufficient understanding about developing process and goal of the system, the developing modes and methods selected by designers did not frequently conform to the actual conditions of the enterprises. As a result, problems arose often in practical application of the system and the desired effect failed to achieve. Therefore, choosing rational method about information system development according to the characteristics of mine enterprise is an issue that must be considered seriously in the establishment of information processing system.

\section{ANALYSIS OF INFORMATION MANAGEMENT STATUS} AND PROBLEMS

As a large-scale mining enterprise, the Gongchangling Mining Corporation faces many problems in daily information management such as comparatively backward method, low efficiency, backward and inconsistent system software, poor security about data storage, and irregularity about daily production reports. So it has a strong demand for speeding up the building of its information system. This paper aims at this demand and tries to put forward the reasonable development strategy of the company's office automation system through comparing several common development strategy of information system.

Gongchangling Mining Corporation is a wholly-owned subsidiary of the Anshan Iron and Steel Group, a famous iron and steel enterprise in China. As one of the main production bases of raw materials of Anshan Iron and Steel Group, the company is a large state-owned miningbeneficiation complex with an annual output of 9 million tons of iron ore and 3.8 million tons of iron concentrate. With the development of computer information technology, the company, based on the construction of enterprise information network platform, had developed a series of information management systems such as ore qualitymeasurement information management, ore processing data management and report system, water supply pipe network information management of ore-dressing plant, large equipment management, and production data acquisition and processing system. To a certain extent, development and application of these systems had improved management efficiency and enhanced information level of the company, however, because these systems were developed at different stages by different departments and developers on the basis of different hardware and software conditions, they were nearly independent of each other. Obviously, it is difficult for these systems to meet the basic need of information collecting, processing and sharing [1-2]. The major problems are in the following respects.

(1) Utilization of computers was very low because they were only used as management tool of single business. In each department, the main function of computers was to gather data and print reports, and the crucial analysis works were completed manually. Between different departments, the lateral flow of information was very poor. For example, because there was no network access to get information from other department, the information management of financial department stayed basically in manual accounting and standalone operation stage.

(2) Instead of querying data at different time point dynamically, company leader could only understand daily production and operation status of some major departments through daily production reports, and for historical data, manual searching was his or her only option. However, the leader could only get some original data or pretreated data after spending much time that could not provide much help for his or her decision. 
(3) Storage format of data was not unified. For example, the quality check department and the open pit mine saved their daily production data in Microsoft Excel format, and the ore-dressing plant stored its data in Foxpro database. Although there was many times of revision, such mode could still not meet the needs of enterprise development.

In order to solve the above problems, a countermeasure that constructed enterprise office automation system is put forward based on systematic analysis of hardware and software conditions in Gongchangling Mining Corporation. The basic thought is to combine JSP technology with MYSQL database technology on the basis of $\mathrm{B} / \mathrm{S}$ framework.

\section{INTEGRATION STRATEGY OF THE SYSTEM}

\section{A. Comparison and selection of the development modes}

At present, $\mathrm{C} / \mathrm{S}$ and $\mathrm{B} / \mathrm{S}$ are the two most important system frameworks that are used in development and application fields of information system. However, how to choose a specific framework in different application environment is a work that needs to make a concrete analysis of specific question, and how to play to enterprise's strengths and select suitable system framework is the key displaying enterprise's resources superiority and deciding success or failure of the system. Table 1 shows the main advantages and disadvantages of $\mathrm{C} / \mathrm{S}$ mode and $\mathrm{B} / \mathrm{S}$ mode [3].

TABLe 1 Performance COMPARISON BeTweEn C/S AND B/S

\begin{tabular}{|c|c|c|}
\hline Performance & $\mathrm{C} / \mathrm{S}$ framework & B/S framework \\
\hline $\begin{array}{l}\text { Hardware } \\
\text { environment }\end{array}$ & $\begin{array}{l}\text { A small-scale network environment } \\
\text { based on special network. } \\
\text { Connection. Data exchange is } \\
\text { finished through special server } \\
\text { between LANs. }\end{array}$ & $\begin{array}{l}\text { A network environment based on WANs. } \\
\text { Special network hardware environment is not } \\
\text { requisite. Connection and data exchange can } \\
\text { be finished through telephone line or rented } \\
\text { equipment. }\end{array}$ \\
\hline $\begin{array}{l}\text { Program } \\
\text { structure }\end{array}$ & $\begin{array}{l}\text { The mode pays more attention to } \\
\text { process. Multi-level check for } \\
\text { permission makes it more safety, } \\
\text { and it pays less attention to } \\
\text { operating speed. }\end{array}$ & $\begin{array}{l}\text { The mode considers both security and access } \\
\text { speed on the basis of optimization. } \\
\text { Relatively, its security is weaker than C/S. }\end{array}$ \\
\hline $\begin{array}{l}\text { Development } \\
\text { costs }\end{array}$ & Low & High \\
\hline $\begin{array}{l}\text { System } \\
\text { maintenance }\end{array}$ & $\begin{array}{l}\text { Application system and database } \\
\text { support software are installed on } \\
\text { client. When the system need to } \\
\text { upgrade, the software on server and } \\
\text { client must be upgraded together. } \\
\text { The maintenance costs and } \\
\text { workload are relatively high. }\end{array}$ & $\begin{array}{l}\text { Application system and database support } \\
\text { software are installed on server. Instead of } \\
\text { installing special software, only the browser } \\
\text { (IE, Netscape, etc.) is needed to install on } \\
\text { client. Thus, only the software on server } \\
\text { needs to be upgraded, and the maintenance } \\
\text { costs and workload are greatly reduced. }\end{array}$ \\
\hline $\begin{array}{l}\text { Handling } \\
\text { problem }\end{array}$ & $\begin{array}{l}\text { The C/S program orients fixed users } \\
\text { in the same region. It associates } \\
\text { highly with the operating systems, } \\
\text { and the systems are generally same. }\end{array}$ & $\begin{array}{l}\text { The B/S program orients different users in } \\
\text { scattered region. Its application is nearly } \\
\text { unrestricted by the operating system platform. }\end{array}$ \\
\hline Scalability & $\begin{array}{l}\text { Depending on the local area } \\
\text { network, the mode has poor } \\
\text { scalability. }\end{array}$ & $\begin{array}{l}\text { The network management system combines } \\
\text { with Internet/Intranet through standard } \\
\text { TCP/IP, HTTP protocol, so it has good } \\
\text { scalability. }\end{array}$ \\
\hline $\begin{array}{l}\text { Information } \\
\text { sharing }\end{array}$ & Low & $\begin{array}{l}\text { As open and standard data format, HTML is } \\
\text { supported by most popular software. } \\
\text { Meanwhile, the MTML technology can make } \\
\text { Browser access a variety of file formats. }\end{array}$ \\
\hline Inter-platform & $\begin{array}{l}\text { Depending on operating system and } \\
\text { application system, it is difficult for } \\
\text { the system to be used on different } \\
\text { platform. }\end{array}$ & $\begin{array}{l}\text { With the development of Internet/Intranet } \\
\text { technology, especially combination of } \\
\text { information dissemination and retrieval } \\
\text { technology based on WEB (HTML, HTTP), } \\
\text { JAVA cross-network operating technology } \\
\text { and CORBA distributed object technology, } \\
\text { the inter-platform of B/S has been greatly } \\
\text { enhanced. }\end{array}$ \\
\hline
\end{tabular}


From Table 1, it can be seen that $\mathrm{C} / \mathrm{S}$ and $\mathrm{B} / \mathrm{S}$ have their own advantages and disadvantages. Which one should be adopt? It is mainly determined by resources conditions, information situation, application purpose and goal of specific enterprise. As far as Gongchangling Mining Corporation is concerned, the authors think that, in order to make the whole informatization problem of the company to be resolved and conform to the trend of enterprise informationization, the $\mathrm{B} / \mathrm{S}$ mode is a more reasonable choice.

\section{B. Comparison and choice of development technology}

The popular development technology for internet application includes JSP (JavaServerPages), PHP (HypertextPreprocessor) and ASP (ActiveServerPages). There are many different viewpoints on how to choice network programming language, in fact, these technologies have their own advantages and disadvantages.

As its advantages, ASP has no need to compile and can directly interpret and operate after linking, but relatively speaking, it has many disadvantages such as slow speed, weak security, poor platform flexibility, etc.

Compared with ASP ${ }^{[4-6]}$, on the one hand, PHP adopts object-oriented programming and can be run on different platform, and its database connection is more convenient duo to providing of standard database interface. On the other hand, PHP lacks of enterprise-level support and its installation are more complicated, and moreover, its security, scalability and speed are a little worse than JSP'.

JSP page is composed of HTML code and embedded JAVA code. Firstly, the server processes the JAVA code after the page is requested by the client, then the generated HTML page is returned to the client browser. JSP has all the characteristics that JAVA has such as easy to use, objectoriented programming, platform independence, safety, reliability, and Internet-oriented. From SERVELET/JSP that can be run through a small JAR documents to transaction and information processing that needs multiple APPLICATION, JAVA shows a great vitality.

For enterprise-level application, safety, speed and platform flexibility are the important factors that must be considered at the premise of realizing basic function. It can be seen from above comparison, JSP has distinct advantage over ASP and PHP on these three aspects. So, no matter from necessity for present system integration of Gongchangling Mining Corporation or from the future extendibility, JSP is the first choice.

\section{Choice of the background database}

Now that the development mode and technology have been determined, the next key problem is what database should be chosen to store data. At present, there are many popular database tools that can be used as background database of enterprise-level application, such as SQL SERVER, ORACLE, SYBASE and so on ${ }^{[7]}$. Taking only the developing costs into account, the authors think MYSQL is a good choice.

MYSQL is a multi-user and multi-thread SQL database server which adopts $\mathrm{C} / \mathrm{S}$ framework. It is composed of a server daemon (Mysqld), many different client program and database.

As a standard language, SQL makes storage, update and access of information more easily. For example, it can be used to search product information and store customer information for the web site, meanwhile, the data storage speed of MYSQL is fast enough and storage ways is flexible(can restore record file and image information). MYSQL aims at high speed, robustness and ease of use. Compared with other similar database, MYSQL has its own advantage of speed.

Based on the characteristics and advantages mentioned above, MYSQL was chosen as background database of the information system in Gongchangling Mining Corporation.

\section{THE SOLUTION}

On the basis of analyzing informatization status in Gongchangling Mining Corporation, considering comprehensively popular development mode and development technology at present, the integrated solutions was put forward ${ }^{[7]}$.

Firstly, the existing application systems distributed in each mining section and ore-dressing plant were retained, and the corresponding works such as daily acquisition and query of data were finished by these systems. In this way, not only could large amount of labor and costs be saved, but also the duplicated construction of related systems was avoided.

Secondly, the dispersive, impeded "information islands" were integrated into a new system through the $\mathrm{B} / \mathrm{S}$ framework. In the new system, not only could each "information island" communicate with each other through granted permission, but also the processed and useful information could be provided in time to enterprise leaders to make their own decisions.

Thirdly, through providing dynamic data interface, the system was linked with external units such as banks, tax bureau and the superior management department. Thus, the flow of information between different departments was realized. The overall solution is shown in Fig.1. 
C/S system expression

layer

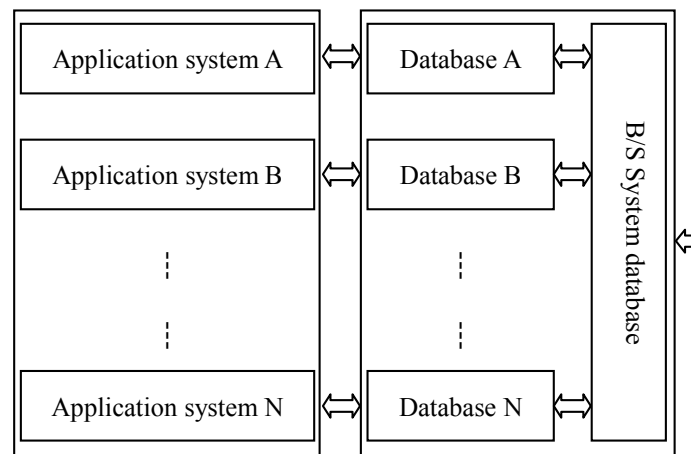

WEB server

B/S system expression layer

(Brower)

Figure 1. B/S solution of OA system in Gongchangling Mining Corporation

\section{CONCLUSIONS}

With the advent of network and information era, new and higher requirements are raised for modern enterprises, especially enterprises engaging in exploitation of mineral resources. To meet the needs, how to make better use of existing resources and advanced information technology is the key. Taking the Gongchangling Mining Corporation for example, an integration scheme of information management is put forward in this paper, including the development mode, development technology, background database and concrete solution. The characteristic of the scheme lies in integrating all sorts of information resources and avoiding duplicate construction of information system. This will provide a quick, accurate and efficient operation platform and help to improve the management decision - making level of the enterprise.

\section{ACKNOWLEDGEMENTS}

The authors thank the anonymous reviewers for their helpful comments and the editors for their work. We acknowledge the National High Technology Research and Development Program of China (863 Program) (No. 2012AA062406).

\section{REFERENCES}

[1] H Y Li, Y M Zheng, "Study status and development trend of office automation," Technology, 2008(17), pp.5-9.

[2] W Zhang, "status of the construction and development trend about Enterprise OA," Office Automation, 2008(18), pp.22-23.

[3] D G Wu, R R Xiao, "Contrast analys on information system of C/S and B/S structure," Information science, 2003,21(3), pp.313-315.

[4] W Chen, "JSP practice of engineering and project," China Machine Press, 2005.

[5] Y Lan, "ASP-based technology of office automation system in network," Office Automation, 2005(1), pp.37-38.

[6] Y L Qu. "The meta to develop dynamic web site in ASP+SQL Server instances," Beijing: Machinery industry press, 2006.

[7] M L Wang, "On the OA system (network office automation) development," Technological sciences, 2008,11. 